\title{
Heavy Metals and Antibiotics Susceptibility Profiles of Staphylococcus aureus Isolated from Several Points Receiving Daily Input from the Bodija Abattoir in Ibadan, Oyo State, Nigeria
}

\author{
Abimbola 0. Adekanmbi, Olutayo I. Falodun* \\ Environmental Microbiology and Biotechnology Laboratory, Department of Microbiology, University of Ibadan, \\ Ibadan, Nigeria \\ Email: ${ }^{\prime}$ falod2013@gmail.com
}

Received 17 November 2015; accepted 27 December 2015; published 30 December 2015

Copyright (C) 2015 by authors and Scientific Research Publishing Inc.

This work is licensed under the Creative Commons Attribution International License (CC BY). http://creativecommons.org/licenses/by/4.0/

(c) (i) Open Access

\section{Abstract}

Indiscriminate and unguided discharge of untreated wastewater especially from abattoirs can constitute a public health threat and also stimulate the onset of co-resistance to metal and antibiotics in environmental microorganisms. It has been shown that microorganisms especially bacteria that have the capacity to resist antibiotics and heavy metals, may constitute a public health threat. This study was therefore conducted to determine the susceptibility and tolerance profile of Staphylococcus aureus isolated from abattoir effluent flowing into a receiving river around Bodija market in Ibadan to a range of antibiotics and heavy metals. Ten points were selected for sampling, and the samples were cultured on nutrient agar and mannitol salt agar. A total of 22 Staphylococcus aureus strains were obtained. They were subjected to increasing concentration of six heavy metals [lead (Pb), copper (Cu), zinc ( $\mathrm{Zn}$ ), chromium (Cr), cadmium (Cd), nickel (Ni)] and five antibiotics. Of the total isolates, $41 \%$ were resistant to all the six metals at $1500 \mu \mathrm{g} / \mathrm{ml}$ concentration, while the others showed various degree of resistance. A percentage resistance of $22.7 \%$ was observed for tetracycline, $100 \%$ to ceftazidime, $9.1 \%$ to ciprofloxacin and vancomycin while $63.6 \%$ of the strains were resistant to oxacillin. All the strains but two showed resistance to all the metals tested, while multiple resistance to antibiotics was also observed. Further studies need to be carried out on the mechanisms of resistance of these strains.

\footnotetext{
*Corresponding author.
} 


\section{Keywords}

\section{Staphylococcus aureus, Heavy Metals, Antibiotics, Abattoir, Resistance}

\section{Introduction}

Abattoir in the developing countries of the world may serve as public health threat due to the unsanitary practices and unwholesome discharge of their waste and wastewater into the environment. Abattoir wastes are parts of the animal that are not used or useful for food productions and may include internal organs, blood, bones, ligaments, tendons, urine, faeces and carcasses [1]. Discharge of waste and wastewater into water surfaces is a common way of contaminating drinking water as such discharge can contain a significant level of bacterial pathogens. Studies on abattoir wastewater and the receiving water had shown that abattoir serves as a source of water pollution as it was reported to contain levels of coliform bacteria that have been found to be far beyond the recommended and permissible limit for discharge into water bodies [2]. It has also been reported that the discharge of untreated abattoir wastewater into drainage channel have led to the contamination of groundwater with faecal bacteria [3]. More so, a number of bacteria and fungi pathogens which might be a public threat by migrating into the groundwater have been reported to have been isolated from wastewater from abattoirs and surface water; these pathogens include: Staphylococcus spp., Escherichia coli, Streptococcus spp., Salmonella spp., Aspergillus spp., Mucor spp., Saccharomyces spp. and Penicillium spp. [4] [5].

Staphylococci are gram positive, ubiquitous bacteria that are part of the normal bacterial flora of the skin and mucosal surfaces of human and animals while Staphylococcus aureus, S. epidermidis and S. saprophyticus have been implicated in human health diseases [6]. Staphylococcus aureus is facultative anaerobe, non-motile, and appear usually in the form of irregular coccoid clusters, and has been implicated as a pathogen in a wide range of human infections, such as skin, soft tissues and wound infections. It is also responsible for some other chronic infections like septicemia, urinary tract infections, pneumonia, osteomyelitis or endocarditis. It is also a common pathogen in both hospital and community-acquired infections [7]-[10].

Heavy metals are found in increasing proportion in microbial habitats as a result of rapid urbanization and natural processes [11]. Metals such as nickel, copper, cobalt and zinc play a major role in the growth and development of microbes as well as their metabolic processes. However, increase in the concentration of the metals beyond threshold compels microorganisms to adapt using various biological mechanisms in other to withstand the condition of the increased concentrations [12] [13]. The presence of high concentration of heavy metals in wastewater not only leads directly to the contamination of receiving water bodies, it also has detrimental effects on the aquatic life of the water bodies [14]. There are various mechanisms by which microorganisms adapt to heavy metals which include: metal sorption, mineralization, uptake and accumulation, metal efflux systems, complexation, oxidation or reduction to a less toxic form by which metals are used as a terminal electron acceptor during anaerobic respiration [15] [16]. Bacteria that can tolerate and grow in the presence of high concentration of heavy metals play important role in their biological cycling and have potential in the remediation of metal-contaminated environment [17]. Staphylococcus aureus have been reported to be resistant to a number of heavy metals such as chromium and iron [18].

Antibiotic resistance in bacteria is the ability of such bacteria to grow in the presence of antibiotics and resistance could be natural or acquired [19]. Infections as a result of resistant bacteria are always difficult to treat because conventional treatment fails and leads to longer time of treatment and sometimes death. It also leads to higher medical costs, according to the World Health Organization [20]. Resistant pathogenic microorganisms can be transmitted to human from animals and non-pathogenic antibiotic resistant bacteria that are part of normal flora of the intestinal tract and are able to transfer resistance genes to non-pathogenic ones [21].

S. aureus is often found to be resistant to one or more antibiotics, including methicillin and hence infections caused by this organism are usually very difficult to treat [22]. Antibiotic resistance in human may either be hospital or community acquired. One of the main contributors to the community acquired infection including Staphylococci infections is the use of antibiotics in animal production and also the introduction of resistant bacteria into the environment through the faeces of animals that are on chemotherapy [23] [24]. This study was therefore designed to determine the susceptibility and tolerance profile of Staphylococcus aureus isolated from an abattoir flowing into a receiving river around Bodija market area in Ibadan, Oyo State to a range of antibiotics and heavy metals. 


\section{Materials and Methods}

\subsection{Description of the Study Area}

The study was carried out on a drainage-river interface receiving everyday input from the Bodija market abattoir and some other sources (e.g. refuse dumpsite, public toilet, household waste, agricultural waste and sewage) all located in Ibadan North LGA of Oyo State. Ten (10) different sampling points approximately 50 meters apart were chosen for the study along the course of the drainage discharge from the abattoir into the adjoining river, except for sampling point 8 and 9 with the separating distance around 500 meters (due to the non-availability of a suitable sampling point). The description and geographical positions of the sampling points are shown in Table 1 (Plate 1).

\subsection{Sample Collection}

A total of 30 wastewater samples (3 for each sampling point) were collected at the designated sampling points in $1.5 \mathrm{~L}$ pre-sterilized sample bottles from July-September, 2014. The wastewater samples were immediately transported to the laboratory in ice packs within 30 minutes of collection for microbiological analysis.

\subsection{Isolation and Characterization of Bacteria from the Wastewater Samples}

Serial dilutions were carried out on the wastewater samples and $1 \mathrm{ml}$ of the appropriate dilution were plated on

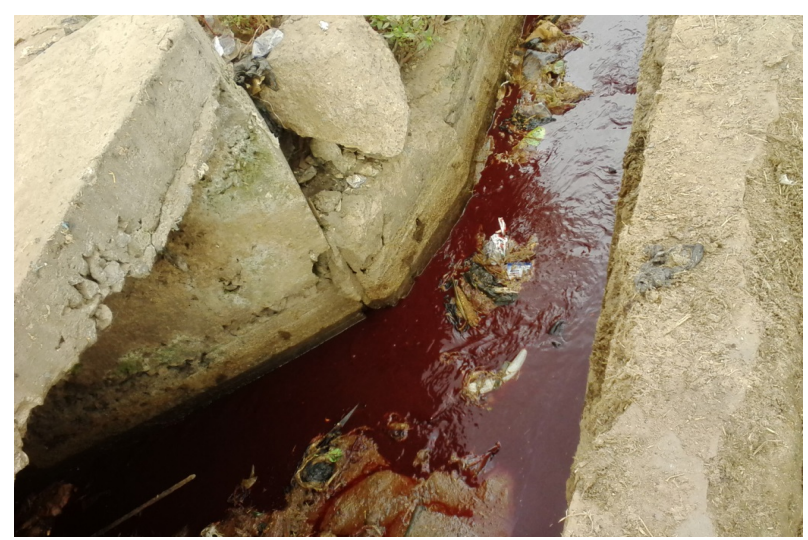

Plate 1. One of the points where wastewater sample was obtained in this study.

Table 1. Description of the sample locations and the geographical positioning reading.

\begin{tabular}{|c|c|c|c|}
\hline $\begin{array}{l}\text { Sampling } \\
\text { points }\end{array}$ & Latitude & Longitude & Description \\
\hline 1 & $7.43985 \mathrm{~N}$ & $3.90268 \mathrm{E}$ & $\begin{array}{l}\text { The point at which animals are being slaughtered and the effluent, } \\
\text { mainly blood is washed down into a nearby drainage channel }\end{array}$ \\
\hline 2 & $7.43966 \mathrm{~N}$ & $3.90252 \mathrm{E}$ & A point on the drainage channel which is located few meters from the initial point of discharge \\
\hline 3 & $7.45241 \mathrm{~N}$ & $3.90991 \mathrm{E}$ & Further extension along the drainage channel \\
\hline 4 & $7.45249 \mathrm{~N}$ & 3.90935E & The point at which there is an input of leachate from a refuse dumpsite into the drainage channel. \\
\hline 5 & $7.45257 \mathrm{~N}$ & 3.90903E & At this point, there are inputs into the drainage channel from residential houses close by. \\
\hline 6 & $7.45073 \mathrm{~N}$ & $3.91025 \mathrm{E}$ & $\begin{array}{l}\text { There is an enormous input from a leaking septic tank and a fully } \\
\text { operational saw mill into the effluent-drainage channel at this point. }\end{array}$ \\
\hline 7 & $7.45073 \mathrm{~N}$ & 3.91093E & $\begin{array}{l}\text { The effluent aggregates at this point and enters a very big drainage } \\
\text { canal which empties its content directly into a river. }\end{array}$ \\
\hline 8 & $7.44628 \mathrm{~N}$ & $3.9138 \mathrm{E}$ & There are numerous inputs into the river at this point from laundry, agricultural and domestic sources. \\
\hline 9 & $7.44686 \mathrm{~N}$ & $3.91358 \mathrm{E}$ & $\begin{array}{l}\text { At this point, the water in the river is very clear with minimal influence from anthropogenic activities. } \\
\text { The only input close to this point is a nearby church. }\end{array}$ \\
\hline 10 & $7.44082 \mathrm{~N}$ & 3.9171E & The point at the other side of the bridge about 50 metres from Point 9 . \\
\hline
\end{tabular}


cooled Nutrient agar (for the determination of the total heterotrophic count) and mannitol salt agar for the isolation of Staphylococcus sp., using the standard pour plate technique of Harrigan and McCance [25]. The plates were incubated at $35^{\circ} \mathrm{C}$ for 24 hours. Distinct yellow colonies presumptive of the target organism were picked and further sub-cultured to obtain pure cultures. The pure isolates were kept on $15 \%$ glycerol stock and kept at $-80^{\circ} \mathrm{C}$ for long term storage. Characterization of the bacterial isolates was done using morphological, biochemical and sugar fermentation tests [26].

\subsection{Exposure of the Bacteria to Increasing Concentration of Heavy Metals}

The tolerance of each Staphylococcal strain to metal ions was evaluated on Mueller Hinton agar plates supple-

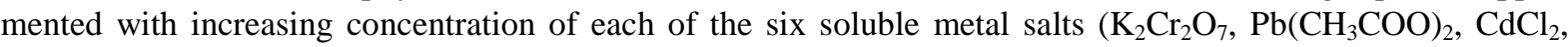
$\mathrm{NiSO}_{4}$ and $\mathrm{CuSO}_{4}, \mathrm{ZnSO}_{4}$ ) employed in this study. The starting concentration of each metal was $50 \mu \mathrm{g} / \mathrm{ml}$ and this was increased by $50 \mu \mathrm{g} / \mathrm{ml}$ at intervals until the isolates failed to grow on the media-supplemented medium. The plates were incubated at $35^{\circ} \mathrm{C} \pm 2^{\circ} \mathrm{C}$ and observed for growth [27] [28].

\subsection{Antibiotic Susceptibility Test}

Antibiotic susceptibility test was carried out using the disc diffusion technique according to the method of Bauer et al. [29]. The five antibiotics used in this study include: ceftazidime $(10 \mu \mathrm{g})$, tetracycline (30 $\mu \mathrm{g})$, ciprofloxacin $(5 \mu \mathrm{g})$, vancomycin $(30 \mu \mathrm{g})$, and oxacilin $(1 \mu \mathrm{g})$. All the antibiotics were purchased from Oxoid, UK. The bacteria were cultivated on Muller Hinton agar plates using sterile swab sticks; after the turbidity of the inoculum have been adjusted to $0.5 \mathrm{McF}$ arland standards. The antibiotic discs were placed on the plates with the aid of sterile forceps and incubated at $35^{\circ} \mathrm{C} \pm 2^{\circ} \mathrm{C}$ for 18 - 24 hours. The zones of inhibition were measured and the values were compared with the CLSI standards [30].

\subsection{Statistical Analysis}

The mean of the data generated were calculated and the standard deviation was determined.

\section{Results}

A total of twenty-two (22) Staphylococcus aureus strains showing different level of resistance to the six metals employed in this study were obtained. The total heterotrophic count (THC) at each point of sampling is shown in Table 2. Wastewater samples collected from sampling point 6 had the highest value of $3.76 \times 10^{7} \mathrm{cfu} / \mathrm{ml}$ while the least value of $0.91 \times 10^{7} \mathrm{cfu} / \mathrm{ml}$ was observed at sampling point 1 . Sampling points 2 and 4 had values of

Table 2. Total Heterotrophic Count at each selected sampling points.

\begin{tabular}{ccc}
\hline Sampling points & Total Heterotrophic Count $\mathbf{( T H C ) \times 1 \mathbf { 0 } ^ { \mathbf { 7 } }}$ \\
\hline $\mathbf{1}$ & $0.91 \pm 0.04$ \\
$\mathbf{2}$ & $1.76 \pm 0.04$ \\
$\mathbf{4}$ & $1.92 \pm 0.02$ \\
$\mathbf{5}$ & $1.76 \pm 0.04$ \\
$\mathbf{6}$ & $1.92 \pm 0.01$ \\
$\mathbf{7}$ & $3.76 \pm 0.1$ \\
$\mathbf{8}$ & $1.40 \pm 0.01$ \\
$\mathbf{9}$ & $3.48 \pm 0.01$ \\
$\mathbf{1 0}$ & $1.08 \pm 0.07$ \\
\hline
\end{tabular}

Note: The values are a mean of three different samplings. 
$1.76 \times 10^{7} \mathrm{cfu} / \mathrm{ml}$ respectively while the samples collected from sampling points 3 and 5 with values of $1.92 \times$ $10^{7} \mathrm{cfu} / \mathrm{ml}$.

The Minimum Inhibitory Concentration (MIC) of the Staphylococcus aureus to increasing concentration of heavy metals is shown in Table 3. All the isolates were observed to be growing at different concentration of the metals except for Staphylococcus aureus AW2a and AW8I that did not grow at any concentration of chromium and nickel respectively.

The resistance pattern of the isolates to the antibiotics used in this study is shown in Figure 1. All the isolates were resistant to ceftazidime (100\%), there was $22.7 \%$ resistance to tetracycline, $9.1 \%$ each to ciprofloxacin and vancomycin while $63.6 \%$ of the Staphylococcus aureus strains were resistant to oxacillin. The phenotype of resistance to the antibiotics is shown in Table 4. It was observed that six (6) of the isolates were resistant to ceftazidime only, seven (7) showed resistance to both ceftazidime and oxacillin; one (1) each to ceftazidime and vancomycin; ceftazidime, oxacillin and ciprofloxacin; and ceftazidime, tetracycline and ciprofloxacin. There were four (4) isolates observed showing resistance to ceftazidime, tetracycline and oxacillin, while two (2) of the 22 isolates showed resistance to the trio of ceftazidime, oxacillin and vancomycin.

\section{Discussion}

Our observation in this study showed that the total heterotrophic count was within the range of $0.91 \times 10^{7}$ and $3.76 \times 10^{7} \mathrm{cfu} / \mathrm{ml}$; points 6 and 8 revealed relatively, higher count. The reason for this high count might be due to the high volume of anthropogenic activities around the two points compared to the other sampling points. The

Table 3. MIC of the isolated Staphylococcus aureus to heavy metals $(\mu \mathrm{g} / \mathrm{ml})$.

\begin{tabular}{|c|c|c|c|c|c|c|}
\hline Bacterial isolates & Lead & Copper & Zinc & Chromium & Cadmium & Nickel \\
\hline AW1c & 500 & 1500 & 500 & 500 & 500 & 500 \\
\hline AW1d & 1500 & 1500 & 1500 & 1500 & 1500 & 1500 \\
\hline AW2a & 1500 & 1500 & 700 & NG & 1500 & 1500 \\
\hline AW2b & 1500 & 1500 & 1500 & 1500 & 600 & 1500 \\
\hline AW3a & 500 & 500 & 500 & 500 & 700 & 500 \\
\hline AW3c & 1500 & 1500 & 600 & 700 & 1500 & 700 \\
\hline AW3d & 1500 & 1500 & 1500 & 1500 & 1500 & 1500 \\
\hline AW4c & 1500 & 100 & 1500 & 1500 & 1500 & 100 \\
\hline AW5a & 1500 & 400 & 1500 & 1500 & 1500 & 1500 \\
\hline AW5b & 1500 & 1500 & 1500 & 1500 & 700 & 1500 \\
\hline AW5c & 1500 & 1500 & 1500 & 1500 & 1500 & 1500 \\
\hline AW6a & 300 & 200 & 200 & 200 & 1500 & 200 \\
\hline AW6e & 1500 & 1500 & 1500 & 1500 & 700 & 1500 \\
\hline AW7c & 1500 & 300 & 600 & 700 & 500 & 500 \\
\hline AW7d & 1500 & 1500 & 1500 & 1500 & 1500 & 1500 \\
\hline AW7e & 1500 & 1500 & 1500 & 1500 & 1500 & 1500 \\
\hline AW7f & 1500 & 1500 & 1500 & 1500 & 1500 & 1500 \\
\hline AW7h & 1500 & 300 & 1500 & 1500 & 500 & 500 \\
\hline AW8d & 1500 & 1500 & 1500 & 1500 & 1500 & 1500 \\
\hline AW8k & 1500 & 1500 & 1500 & 1500 & 1500 & 1500 \\
\hline AW81 & 1500 & 600 & 1500 & 1500 & 1500 & NG \\
\hline AW9a & 1500 & 200 & 1500 & 1500 & 1500 & 1500 \\
\hline
\end{tabular}




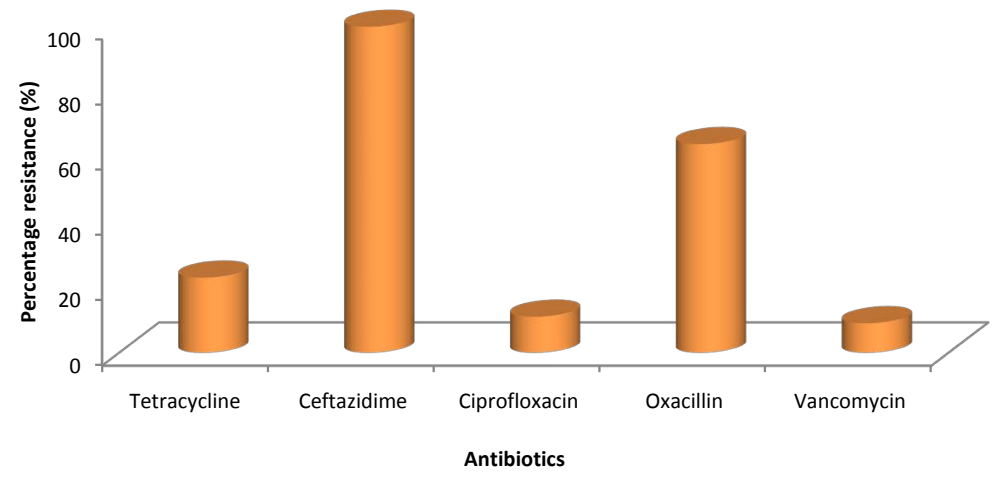

Figure 1. Percentage resistance of Staphylococcus aureus strains to the selected antibiotics.

Table 4. Phenotypic resistance pattern of Staphylococcus aureus to metals and antibiotics used in this study.

\begin{tabular}{|c|c|c|}
\hline Isolate code & Heavy metal resistance pattern & Phenotype of resistance \\
\hline AW1c & $\mathrm{Pb}, \mathrm{Cu}, \mathrm{Zn}, \mathrm{Cr}, \mathrm{Cd}, \mathrm{Ni}$ & $\mathrm{CAZ}^{1}$ \\
\hline AW1d & $\mathrm{Pb}, \mathrm{Cu}, \mathrm{Zn}, \mathrm{Cr}, \mathrm{Cd}, \mathrm{Ni}$ & $\mathrm{CAZ}^{1}, \mathrm{OX}^{2}$ \\
\hline AW2a & $\mathrm{Pb}, \mathrm{Cu}, \mathrm{Zn}, \mathrm{Cd}, \mathrm{Ni}$ & $\mathrm{CAZ}^{1}$ \\
\hline AW2b & $\mathrm{Pb}, \mathrm{Cu}, \mathrm{Zn}, \mathrm{Cr}, \mathrm{Cd}, \mathrm{Ni}$ & $\mathrm{CAZ}^{1}, \mathrm{VA}^{3}$ \\
\hline AW3a & $\mathrm{Pb}, \mathrm{Cu}, \mathrm{Zn}, \mathrm{Cr}, \mathrm{Cd}, \mathrm{Ni}$ & $\mathrm{CAZ}^{1}, \mathrm{OX}^{2}$ \\
\hline AW3c & $\mathrm{Pb}, \mathrm{Cu}, \mathrm{Zn}, \mathrm{Cr}, \mathrm{Cd}, \mathrm{Ni}$ & $\mathrm{CAZ}^{1}, \mathrm{CIP}^{4}, \mathrm{OX}^{2}$ \\
\hline AW3d & $\mathrm{Pb}, \mathrm{Cu}, \mathrm{Zn}, \mathrm{Cr}, \mathrm{Cd}, \mathrm{Ni}$ & $\mathrm{CAZ}^{1}, \mathrm{TET}^{5}, \mathrm{OX}^{2}$ \\
\hline AW4c & $\mathrm{Pb}, \mathrm{Cu}, \mathrm{Zn}, \mathrm{Cr}, \mathrm{Cd}, \mathrm{Ni}$ & $\mathrm{CAZ}^{1}, \mathrm{OX}^{2}$ \\
\hline AW5a & $\mathrm{Pb}, \mathrm{Cu}, \mathrm{Zn}, \mathrm{Cr}, \mathrm{Cd}, \mathrm{Ni}$ & $\mathrm{CAZ}^{1}$ \\
\hline AW5b & $\mathrm{Pb}, \mathrm{Cu}, \mathrm{Zn}, \mathrm{Cr}, \mathrm{Cd}, \mathrm{Ni}$ & $\mathrm{CAZ}^{1}, \mathrm{TET}^{5}, \mathrm{CIP}^{4}$ \\
\hline AW5c & $\mathrm{Pb}, \mathrm{Cu}, \mathrm{Zn}, \mathrm{Cr}, \mathrm{Cd}, \mathrm{Ni}$ & $\mathrm{CAZ}^{1}$ \\
\hline AW6a & $\mathrm{Pb}, \mathrm{Cu}, \mathrm{Zn}, \mathrm{Cr}, \mathrm{Cd}, \mathrm{Ni}$ & $\mathrm{CAZ}^{1}, \mathrm{OX}^{2}, \mathrm{VA}^{3}$ \\
\hline AW6e & $\mathrm{Pb}, \mathrm{Cu}, \mathrm{Zn}, \mathrm{Cr}, \mathrm{Cd}, \mathrm{Ni}$ & $\mathrm{CAZ}^{1}, \mathrm{TET}^{5}, \mathrm{OX}^{2}$ \\
\hline AW7c & $\mathrm{Pb}, \mathrm{Cu}, \mathrm{Zn}, \mathrm{Cr}, \mathrm{Cd}, \mathrm{Ni}$ & $\mathrm{CAZ}^{1}, \mathrm{OX}^{2}$ \\
\hline AW7d & $\mathrm{Pb}, \mathrm{Cu}, \mathrm{Zn}, \mathrm{Cr}, \mathrm{Cd}, \mathrm{Ni}$ & $\mathrm{CAZ}^{1}, \mathrm{TET}^{5}, \mathrm{OX}^{2}$ \\
\hline AW7e & $\mathrm{Pb}, \mathrm{Cu}, \mathrm{Zn}, \mathrm{Cr}, \mathrm{Cd}, \mathrm{Ni}$ & $\mathrm{CAZ}^{1}, \mathrm{TET}^{5}, \mathrm{OX}^{2}$ \\
\hline AW7f & $\mathrm{Pb}, \mathrm{Cu}, \mathrm{Zn}, \mathrm{Cr}, \mathrm{Cd}, \mathrm{Ni}$ & $\mathrm{CAZ}^{1}$ \\
\hline AW7h & $\mathrm{Pb}, \mathrm{Cu}, \mathrm{Zn}, \mathrm{Cr}, \mathrm{Cd}, \mathrm{Ni}$ & $\mathrm{CAZ}^{1}, \mathrm{OX}^{2}$ \\
\hline AW8d & $\mathrm{Pb}, \mathrm{Cu}, \mathrm{Zn}, \mathrm{Cr}, \mathrm{Cd}, \mathrm{Ni}$ & $\mathrm{CAZ}^{1}, \mathrm{OX}^{2}$ \\
\hline AW8k & $\mathrm{Pb}, \mathrm{Cu}, \mathrm{Zn}, \mathrm{Cr}, \mathrm{Cd}, \mathrm{Ni}$ & $\mathrm{CAZ}^{1}, \mathrm{OX}^{2}$ \\
\hline AW81 & $\mathrm{Pb}, \mathrm{Cu}, \mathrm{Zn}, \mathrm{Cr}, \mathrm{Cd}$ & $\mathrm{CAZ}^{1}$ \\
\hline AW9a & $\mathrm{Pb}, \mathrm{Cu}, \mathrm{Zn}, \mathrm{Cr}, \mathrm{Cd}, \mathrm{Ni}$ & $\mathrm{CAZ}^{1}, \mathrm{OX}^{2}, \mathrm{VA}^{3}$ \\
\hline
\end{tabular}

${ }^{1}$ Ceftazidime, ${ }^{2}$ Oxacillin, ${ }^{3}$ Vancomycin, ${ }^{4}$ Ciprofloxacin, ${ }^{5}$ Tetracycline.

least total heterotrophic count was at the sampling point 1 which is the abattoir wastewater which is devoid of any input from human influence. This observation is similar to other studies carried out in Southern Nigeria, 
where it was reported that abattoir sewage had the lowest total heterotrophic count compared to when the wastewater had mixed with the receiving water bodies and the count from soil or sediment from the abattoir respectively [31] [33]. However, the value of the heterotrophic count in this study $\left(0.9 \times 10^{7}\right)$ is higher than the 1.2 $\times 10^{6}$ as it was reported by Ogbonna [32]. However, a lower total bacterial count $\left(3.6-6.4 \times 10^{1}\right)$ compared to the one observed in this study was reported by Adekanmbi and Falodun [28], in a study carried out on water samples collected from a river that is close to a tertiary hospital with human activities such as car washing, laundry, bathing, swimming and fishing influencing its quality, but the present study was carried out on abattoir wastewater, however, similar activities were observed in both instances.

The isolation of Staphylococcus aureus from Bodija abattoir wastewater (affected by other anthropogenic influence) in this study corroborates previous research which reported the isolation of pathogenic microorganisms including S. aureus from the same abattoir and other abattoirs in the country [31] [32]. Furthermore a study on the physicochemical analyses of the Bodija abattoir wastewater indicated varying concentration of heavy metals like lead, nickel, copper and zinc in the wastewater [33]. Our results showed that out of $95.5 \%$ of the S. aureus strains which were highly resistant to chromium, $72.7 \%$ tolerated the metals at $1500 \mu \mathrm{g} / \mathrm{ml}$ and this was similar to a recent observation in India where all the pathogenic strains of $S$. aureus were resistant to the same metal [18]. Our observation also showed that $72.7 \%$ and $63.6 \%$ of these organisms tolerated $1500 \mu \mathrm{g} / \mathrm{ml}$ of zinc and nickel, respectively. Singh and his colleagues also reported that all the $S$. aureus isolates were susceptible to the two metals [18]. Furthermore, a Staphylococcus isolates was reported to tolerate $100 \mu \mathrm{g} / \mathrm{ml}$ of lead while this same isolate tolerated zinc up to the concentration of $450 \mu \mathrm{g} / \mathrm{ml}$ [34]. Clinical strains of S. aureus also showed tolerance to lead with MIC values ranging between $100 \mu \mathrm{g} / \mathrm{ml}$ to $150 \mu \mathrm{g} / \mathrm{ml}$ [35].

In a study conducted on soil irrigated with wastewater, 100\%, of the Staphylococcus and Micrococcus were resistant to lead and nickel while $83 \%$ were resistant to copper [36]. This is also similar to the results of the present study where $100 \%$ of the isolates were resistant to both copper and lead while $95.5 \%$ of the isolates were resistant to nickel. The result also showed that $90.9 \%$ of the total isolates exhibited tolerance to the metals tested with minimum tolerance level ranging from $100 \mu \mathrm{g} / \mathrm{ml}$ to $500 \mu \mathrm{g} / \mathrm{ml}$ except for $S$. aureus AW2a and AW8l that were susceptible to nickel and chromium. This is in agreement with the report of Rajbanshi [16] that Staphylococcus sp. from sewage treatment plants showed high resistance to heavy metals like cadmium, nickel, copper and chromium with the minimum inhibitory concentration of between $150-500 \mu \mathrm{g} / \mathrm{ml}$.

The S. aureus obtained in this study were all resistant to copper and zinc, but in another study carried out on metal tolerance involving S. epidermidis, it was reported that all the isolates tested were resistant to zinc but susceptible to copper [37]. This may be as a result of the environment from where the organisms were isolated which was not indicated in the report. Our results indicated that $36.4 \%$ of the isolates tolerated a concentration of $1500 \mu \mathrm{g} / \mathrm{ml}$ of all the six metals tested while $22.7 \%$ tolerated five out of the metals at concentration of 1500 $\mathrm{ug} / \mathrm{ml}$. The reason for the variation in the resistance level of the isolates tested in this study may be due to the different levels of the metals in the abattoir. In a previous study on the physicochemical analyses of the effluents from the same abattoir, the concentration of the metals varies but was all beyond the permissible limit of the Federal Ministry of Environment [33].

In case of antibiotic resistance, the result showed that all the isolates were resistant to ceftazidime (10 $\mu \mathrm{g})$, this is similar to the report of Al-Sa'ady et al. [37] in which all the strains of Staphylococcus epidermidis were observed to be resistant to the same antibiotic but the concentration used was not indicated. However, there was a difference in the susceptibility of the strains to tetracycline, which revealed that all the strains of the S. epidermidis were susceptible while $22.7 \%$ of the isolates in this study were resistant to $30 \mu$ g of tetracycline.

Our observation revealed that $63.6 \%$ of the isolates were resistant to oxacillin which is greater than the $24.0 \%$ reported from wastewater that originated from slaughter houses and municipal sources in Germany by Bohn et al. [23]. The difference could be because of a better regulatory measure on abattoir management and disposal of wastes and wastewater in developed countries like Germany compared to a developing country like Nigeria. In a study carried out on strains of Methicillin Resistant Staphylococcus aureus (MRSA) obtained from wastewater treatment plants in the United States [38], it was reported that a percentage resistance of $98.8 \%$ was observed to oxacillin, and this was higher than the $63.3 \%$ resistance to the same antibiotics observed in this study. The percentage resistance to ciprofloxacin in this study was $9.1 \%$ which is much lower when compared to the $63.1 \%$ in the aforementioned study in the United States. Resistance to both tetracycline and vancomycin in this present study was $22.7 \%$ and $9.1 \%$ respectively, which is comparable to the $14.3 \%$ and $0 \%$ resistance, respectively, as reported by Goldstein et al. [38]. 
It was observed in this study that most of the S. aureus tested in this study showed multiple resistances to heavy metals and antibiotics. This observation is similar to a study carried out in Nepal on sewage treatment plant [16]. It has been reported that microbial resistance to heavy metals may be attributed to a variety of detoxifying mechanisms developed by resistant microorganisms such as complexation by exopolysaccharides, binding with bacterial cell envelopes, metal reduction, metal efflux. Sometimes, some of these mechanisms are encoded in plasmid genes which may facilitate the transfer of the toxic metal resistance from the cell of one microorganism to another [39]. Although certain metals are important and essential trace elements in microbial metabolisms and some physiological functions, they can be very toxic above a certain threshold. These interactions have a number of important environmental and health implications.

The use of bacteria to clean up metal-contaminated sites is a useful implication in environmental recovery; however the presence of metal tolerance mechanisms may also contribute to the increase in antibiotic resistance thus contributing to very serious health concerns. The introduction of toxicants such as disinfectants and metals by humans into the environment can have many effects, not just on humans, but also on the environment and the microbial community on which all other life forms depend [40]-[42]. The metal tolerant nature of the bacteria from this study has tremendous potential in the bioremediation of heavy metal contamination in soils and water [43] and also in the treatment of sewage and toxic wastes [44].

\section{Conclusion}

Despite the bioremediation potentials of the Staphylococcus strains isolated in this study, the probable transfer of potentially pathogenic bacteria with metal and antibiotic resistant mechanisms is also a major public health threat. We therefore emphasize the need for adequate measures to be put in place in our abattoirs for a proper treatment of heavy-metal laden wastewater and safe disposal to prevent a potential menace.

\section{Acknowledgements}

The authors would like to acknowledge Miss Oluwaferanmi Joy Adeleke and Nifemi Bunmi Ogunrinde for their inputs.

\section{Conflict of Interests}

The authors did not declare any conflict of interests.

\section{References}

[1] Adeyemi, I.G. and Adeyemo, O.K. (2007) Waste Management Practices at the Bodija Abattoir, Nigeria. International Journal Environmental Studies, 64, 71-82. http://dx.doi.org/10.1080/00207230601124989

[2] Nafanda, W.D. (2005) Implications of Abattoir Waste on the Environment and Public Health in Ibadan and Yola, Nigeria. Journal of Animal Science, 75, 1541-1655.

[3] Adeyemo, O.K., Ayodeji, I.O. and Aiki-Raji, C.O. (2002) The Water Quality and Sanitary Condition in Major Abattoir in Ibadan, Nigeria. African Journal of Biotechnology, 5, 51-55.

[4] Gauri, S.M. (2004) Characterization of Effluent Waste Water from Abattoirs for Land Applications. Food Review International, 20, 229-256. http://dx.doi.org/10.1081/FRI-200029422

[5] Adesemoye, A.O., Opere, B.O. and Makinde, S.O. (2006) Microbial Content of Abattoir Wastewater and Its Contaminated Soil in Lagos, Nigeria. African Journal of Biotechnology, 8, 1963-1968.

[6] Simeonia, D., Rizzottia, L., Cocconcellib, P., Gazzolab, S., Dellaglioa, F. and Torriania, S. (2008). Antibiotic Resistance Genes and Identification of Staphylococci Collected from the Production Chain of Swine Meat Commodities. Food Microbiology, 25, 196-201. http://dx.doi.org/10.1016/j.fm.2007.09.004

[7] Lindsay, J.A. and Holden, M.T. (2004) Staphylococcus aureus: Superbug, Super Genome? Trends in Microbiology, 12, 378-385. http://dx.doi.org/10.1016/j.tim.2004.06.004

[8] Bassetti, M., Nicco, E. and Mikulska, M. (2009) Why Is Community-Associated MRSA Spreading across the World and How Will It Change Clinical Practice? International Journal of Antimicrobial Agents, 34, S15-S19. http://dx.doi.org/10.1016/S0924-8579(09)70544-8

[9] Taylor, A.R. (2013) Methicillin-Resistant Staphylococcus aureus Infections. Primary Care, 40, 637-654. http://dx.doi.org/10.1016/j.pop.2013.06.002 
[10] Zuniga, R. and Nguyen, T. (2013) Skin Conditions: Emerging Drug-Resistant Skin Infections and Infestations. American Academy of Family Physicians, 407, 17-23.

[11] Issazadeh, K., Jahanpour, N., Pourghorbanali, F., Raeisi, G. and Faekhondeh, J. (2013) Heavy Metals Resistance by Bacterial Strains. Annals of Biological Research, 4, 60-63.

[12] Nikaido, H. (2009) Multidrug Resistance in Bacteria. Annual Review of Biochemistry, 78, 119-146. http://dx.doi.org/10.1146/annurev.biochem.78.082907.145923

[13] Tamer, A., Aysenur, K. and Sadik, D. (2013) Antibiotic Levels and Heavy Metal Resistance in Gram-Negative Bacteria Isolated from Seawater, Iskenderun Organized Industrial Zone. Journal of Applied Biological Sciences, 7, 10-14.

[14] Moten, A.M. and Rehman, A. (1998) Study on Heavy Trace Metal Ions in Industrial Waste Effluent in Pakistan. Environmental-Expert.com, Article 909.

[15] Joshi-Tope, G. and Francis, A.J. (1995) Mechanisms of Biodegradation of Metal-Citrate Complexes by Pseudomonas fluorescens. Journal of Bacteriology, 177, 1989-1993.

[16] Rajbanshi, A. (2008) Study on Heavy Metal Resistant Bacteria in Guheswori Sewage Treatment Plant. Our Nature, 6, 52-57.

[17] Nyamboya, R.A., Okemo, P.O. and Ombori, O. (2013) Heavy Metal and Associated Antibiotic Resistance of Fecal Coliforms, Fecal Streptococci and Pathogens Isolated from Wastewaters of Abattoirs in Nairobi, Kenya. Journal of Applied Biosciences, 64, 4858-4866. http://dx.doi.org/10.4314/jab.v64i1.88476

[18] Singh, A., Mishra, M., Tripathi, P. and Sachan, S. (2015) Resistance of Heavy Metals on Some Pathogenic Bacterial Species. African Journal of Microbiology Research, 9, 1162-1164. http://dx.doi.org/10.5897/AJMR2014.7344

[19] European Centre for Disease Prevention and Control (2013) Factsheet for Experts.

[20] WHO: World Health Organization (2013) Water-Related Diseases. 22 August 2013, 29. http://www.who.int/water_sanitation_health/diseases/diarrhoea/en/index.html

[21] Blake, D.P., Hillman, K., Fenlon, D.R. and Low, J.C. (2003) Transfer of Antibiotic Resistance between Commensal and Pathogenic Members of the Enterobacteriaceae under Ideal Conditions. Journal of Applied Microbiology, 95, 428-436. http://dx.doi.org/10.1046/j.1365-2672.2003.01988.x

[22] Goldstein, R.E.R., Micallef, S.A., Gibbs, S.G., Davis, J.A., He, X., George, A., Kleinfelter, L.M., Schreiber, N.A., Mukherjee, S., Sapkota, A., Joseph, S.W. and Sapkota, A.R. (2012) Methicillin-Resistant Staphylococcus aureus (MRSA) Detected at Four U.S. Wastewater Treatment Plants. Environmental Health Perspective, 120, 1551-1558. http://dx.doi.org/10.1289/ehp.1205436

[23] Böhm, R., Gözalan, F. and Philipp, W. (2004) Comparative Study on Antibiotic Resistance in Selected Bacterial Species Isolated from Wastewater Originating from Slaughterhouses and of Municipal Sources. International Society for Animal Hygièn-Saint-Malo, 277.

[24] Nageswaran, N., Ramteke, P.W., Verma, O.P. and Pande, A. (2012) Antibiotic Susceptibility and Heavy Metal Tolerance Pattern of Serratia marcescens Isolated from Soil and Water. Journal of Bioremediation \& Biodegradation, 3, 158. http://dx.doi.org/10.4172/2155-6199.1000158

[25] Harrigan, W.F. and McCance, M.E. (1976) Laboratory Methods in Food and Dairy Microbiology. Academic Press Incorporated, London.

[26] Sneath, P.H.A. (1996) Bergey’s Manual of Determinative Bacteriology. William and Wilkins, Baltimore.

[27] Singh, V., Chauhan, P.K., Kanta, R., Dhewa, T. and Kumar, V. (2010) Isolation and Characterization of Pseudomonas Resistant to Heavy Metals Contaminants. International Journal of Pharmaceutical Sciences Review and Research, 3, 164-167.

[28] Adekanmbi, A.O. and Falodun, O.I. (2015) Physicochemical, Microbiological and Heavy Metal Studies on Water Samples and Bacteria Obtained from Dandaru River in Ibadan, South-Western Nigeri. African Journal of Microbiology Research, 9, 1357-1365. http://dx.doi.org/10.5897/AJMR2015.7388

[29] Bauer, A.W., Kirby, W.M., Sherrie, J.C. and Turk, M. (1996) Antibiotic Susceptibility Testing by a Standardized Single Disk Diffussion Method. American Journal Clinical Pathology, 45, 493-496.

[30] Clinical and Laboratory Standards Institute (2014) Performance Standards for Antimicrobial Susceptibility Testing. 24th Informational Supplement, January 2014.

[31] Ogunnusi, T.A. and Dahunsi, O.V. (2014) Isolation and Identification of Microorganisms from Abattoir Effluents from Oyo, Oyo State, Nigeria. Asian Journal of Applied Sciences, 2, 218-222.

[32] Ogbonna, D.N. (2014) Distribution of Microorganisms in Water, Soils and Sediment from Abattoir Wastes in Southern Nigeria. International Journal of Current Microbiology and Applied Sciences, 3, 1183-1200.

[33] Osibanjo, O. and Adie, G.U. (2007) Impact of Effluent from Bodija Abattoir on the Physicochemical Parameters of 
Oshunkaye Stream in Ibadan City, Nigeria. African Journal of Biotechnology, 6, 1806-1811.

[34] Khare, S., Ahmed, N., Pant, S. and Das, R. (2010) Characterization and Evaluation of Heavy Metal Tolerance of Bacterial Species from Soil of Waste Area near Riyan Steel Rolling Mills, Muzaffarnagar, India. Journal of Applied Natural Science, 2, 88-92.

[35] Garhwal, D., Vaghela, G., Panwala, T., Revdiwala, S., Shah, A. and Mulla, S. (2014) Lead Tolerance Capacity of Clinical Bacterial Isolates and Change in Their Antibiotic Susceptibility Pattern after Exposure to a Heavy Metal. International Journal of Medicine and Public Health, 4, 253-256. http://dx.doi.org/10.4103/2230-8598.137711

[36] Bahig, A.E., Aly, E.A., Khaled, A.A. and Amel, K.A. (2008) Isolation, Characterization and Application of Bacterial Population from Agricultural Soil at Sohag Province, Egypt. Malaysian Journal of Microbiology, 4, 42-50.

[37] AL-Sa’ady, A.R., Shaker, W. and Salam, M. (2014) Antibiotic Susceptibility and Heavy Metal Tolerance Pattern of Staphylococcus epidermidis, and Curing of Plasmid. Current Research in Microbiology and Biotechnology, 2, $402-$ 405.

[38] Goldstein, R.E.R., Micallef, S.A., Gibbs, S.G., Davis, J.A., He, X., George, A., Kleinfelter, L.M., Schreiber, N.A., Mukherjee, S., Sapkota, A., Joseph, S.W. and Sapkota, A.R. (2012) Methicillin-Resistant Staphylococcus aureus (MRSA) Detected at Four U.S. Wastewater Treatment Plants. Environmental Health Perspective, 120, 1551-1558. http://dx.doi.org/10.1289/ehp.1205436

[39] Silver, S. (1996) Bacterial Resistances to Toxic Metal Ions-A Review. Gene, 179, 9-19. http://dx.doi.org/10.1016/S0378-1119(96)00323-X

[40] Monchy, S., Benotmane, A., Janssen, P., Vallaeys, T., Taghavi, S., van der Lelie, D. and Mergeay, M. (2003) Ralstonia metallidurans, a Bacterium Specifically Adapted to Toxic Metals: Towards a Catalogue of Metal Resistance Genes. FEMS Microbiology Reviews, 27, 385-410. http://dx.doi.org/10.1016/S0168-6445(03)00045-7

[41] Spain, A. (2003) Implications of Microbial Heavy Metal Tolerance in the Environment. Reviews in Undergraduate Research, 2, 1-6.

[42] Samanta, A., Bera, P., Khatun, M., Sinha, C., Pal, P., Lalee, A. and Mandal, A. (2012) An Investigation on Heavy Metal Tolerance and Antibiotic Resistance Properties of Bacterial Strain Bacillus sp. Isolated from Municipal Waste. Journal of Microbiology and Biotechnology Research, 2, 178-189.

[43] Karthikeyan, R. and Kulakow, P.A. (2003) Soil Plant Microbe Interactions in Phytoremediation. Advances in Biochemical Engineering/Biotechnology, 78, 52-74. http://dx.doi.org/10.1007/3-540-45991-x_2

[44] McIntyre, T. (2003) Phytoremediation of Heavy Metals from Soils. Advances in Biochemical Engineering/Biotechnology, 78, 97-123. http://dx.doi.org/10.1007/3-540-45991-x_4 